\title{
Leituras ambientais na paisagem transformada
}

Eduardo Louis Jacob

Programador visual, atua em comunicaşão gráfico-ambiental na TSO Comunicação Visual.

Especialista em Gestão de Processos Comunicacionais e mestrando na PUC/SP.

E-mail: eddieloja@gmail.com

A exposição de poesia no interior das estações do Metrô paulistano, utilizando os recursos da Comunicação Gráfico-Ambiental - CGA, foi a proposta de gestão da comunicação apresentada aos autores do projeto Poesia no Metrô: olhares na paisagem urbana, e tema deste artigo. A comunicação gráfico-ambiental é um conceito com o qual trabalho há algum tempo. Nesse caso, sua aplicação é de suma importância, pois constitui a interface entre o discurso poético e o público receptor. Ela é quem dá forma e substância ao projeto e transforma o ambiente em outro discurso, potencializando o espaço do Metrô como suporte para comunicação. O projeto de gestão preocupou-se em verificar a sua adequação e o nível do repertório dos usuários, como também identificar qual a forma mais adequada de apresentar a poesia ao público, caminho que conduz à CGA.

A proposta de intervenção surgiu quando o escritor e poeta Carlos Figueiredo, idealizador e responsável pela seleção dos textos poéticos, e o artista plástico Antonio Peticov, encarregado de aplicar e dar aparência aos textos, procuraram descobrir a melhor forma de executar a exposição. O objetivo deles é, através do contato contemplativo, estimular o público a estabelecer um hábito freqüente de leitura de elementos literários, especificamente os poéticos.

O intuito dos artistas é proporcionar um contato direto com manifestações poéticas de diferentes matrizes e, a partir do impacto e estranhamento causados pela intervenção, perpetrar uma ruptura nas formas tradicionais de perceber a poesia e incorporá-la naturalmente em seu cotidiano. O projeto foi de início recebido pelo gestor para verificar sua viabilidade técnica e operacional. Submetido à luz da gestão da comunicação e a uma análise bem mais ampliada dos seus elementos constitutivos, revela a figura do gestor de comunicação como mediador entre a proposta dos autores e o público-alvo. Os preceitos assumidos pelo trabalho partem da classificação do projeto como uma intervenção urbana. Para o amplo entendimento desse conceito, buscou-se a compreensão das noções aqui envolvidas, cada qual isoladamente:

- Intervenção: o ponto de partida é a interferência em sítios específicos com recursos do que se convencionou aqui chamar de comunicação gráfico-ambiental.

- Urbano: ao explorar o universo da paisagem urbana em sua integralidade, a metrópole. 
O entendimento do mundo a partir da experiência da informação nova é a principal preocupação desse trabalho. Ao selecionar o ambiente das estações de Metrô, há um recorte em uma perspectiva significativamente mais vasta. Dali para fora: a cidade. A capacidade de contemplação dos indivíduos é discutida dentro da equação mobilidade versus exposição que pode resultar em alteração da percepção das variáveis ambientais e conseqüentes mudanças comportamentais. Ao se deslocar os elementos a serem contemplados para lugares primariamente tipificados com base em outra lógica informacional, regenera-se o manancial de significados presentes nesses espaços públicos, reprogramando a significação de tais espacialidades, ao transformar as paisagens em informação.

\section{APRENDENDO A TER EXPERIÊNCIAS}

A pergunta que o trabalho de intervenção se fez a todo instante foi: se colocarmos elementos de distração nos caminhos, em coexistência com outros dotados de ênfases puramente urbanísticas e arquitetônicas, que sensibilizem o transeunte e o despertem para o seu entorno, poderá ser recriada uma maneira de o cidadão lidar com a cidade?

Percebe-se que a CGA possibilita que as pessoas manipulem os significados das espacialidades concebidas, redimensionando as próprias interações decorrentes, com vistas ao estabelecimento de novos referenciais consensuais. Dessa maneira, os textos gráficos (tanto palavra como imagem) podem ser incorporados em um ambiente informacional completo que procura moldar as mentes de seus usuários e proporcionar experiências sensórias que promovam alterações em sua espacialidade e em seu comportamento. Uma conexão orgânica fincada entre a comunicação gráfico-ambiental e uma construção ambiental antevê uma relação espacial entre o observador e o ambiente, na qual a CGA funciona como dispositivo tecnológico de mediação, indicando não só o uso social daquele ambiente, mas também agindo como uma escritura sem palavras de um texto sem autor. A comunicação gráfico-ambiental e sua significação se concretizam quando a presença de tal comunicação produz uma resposta sensível nas pessoas. Aprendemos a ter experiências no interior desses sistemas ambientais. Nesse caso, o indivíduo constrói internamente - através da observação - a informação sobre o seu ambiente, a partir de um programa tutorial de propagação informacional, de responsabilidade dos atores comunicativos que interagem dentro desse sistema, que nos sugere e nos convida a associações de ecologia e cultura.

Falar da relação do indivíduo com o mundo é falar de percepção ambiental. Para Ferrara, são os

usos e hábitos reunidos que constroem a imagem do lugar, mas sua característica de rotina cotidiana projeta sobre ela uma membrana de opacidade que impede sua percepção, tornando o lugar, tal como o espaço, homogêneo e inteligível, sem decodificação ${ }^{1}$.

FERRARA, Lucrécia D'Alessio. Olhar periférico. São Paulo: Edusp, 1993. p. 153

O perigo de a percepção ser contaminada ou deformada, portanto, pode se dar no sentido da acomodação, em que uma dada paisagem torna-se tão 
familiar que mal a percebemos mais como informação. Para a autora, superar essa opacidade é condição de percepção ambiental. O processo de gerar informação (pela percepção) a partir de uma informação (ambiente) é chamado de percepção ambiental, condicionada pela revelação dos signos do lugar informado. Quanto mais homogêneo é o ambiente, menor é a sua legibilidade. O máximo de homogeneidade permite o mínimo de leitura. Só lemos o que é heterogêneo ou o que se torna saliente à nossa observação pela ruptura dos hábitos e costumes. O texto ambiental não é imposto. Pelo contrário, ele não nos cobra atenção. Por isso, o "hábito de atuar nos mesmos espaços e ambientes faz com que eles sejam cada vez mais iguais e imperceptíveis"² para os indivíduos.

Sabemos identificar as coisas ao nosso redor antes mesmo de aprendermos as palavras que representam essas coisas. As cidades, as ruas, são o pano de fundo, o cenário no qual nossas vidas são encenadas. Se, como as crianças, que ao brincar nas ruas percebem como naturais os elementos que compõem seus ambientes familiares e sociais, com a mesma naturalidade, quando adultas, notarão o mundo ao seu redor, não reagindo, por não possuírem repertório alternativo, à transformação da paisagem que as cerca. Paulo Freire acerta ao dizer "que a leitura da palavra não é apenas precedida pela leitura do mundo, mas por certa forma de 'escrevê-lo' ou de 'reescrevê-lo', quer dizer, de transformá-lo através de nossa prática consciente" . Posto que o significado, o sentido dos lugares, muda constantemente em função dos diversos usos, dos processos que ocorrem com aqueles lugares. Toda relação com um determinado lugar é uma tentativa de ler e capturar os diferentes sentidos possíveis desse lugar, pois "não há um sentido, mas sentidos produzidos que não se impõem"4.

Surge a idéia de interpretação: a comunicação gráfico-ambiental está constantemente interpretando o lugar. A CGA qualifica o lugar para o observador que por ali se desloca, estabelecendo uma relação entre esse observador e o lugar identificado. E o que se vê são essas estratégias de leitura, mais do que propriamente os lugares em si, porque eles mesmos podem se revestir de vários significados.

\section{A COMUNICAÇÃO GRÁFICO-AMBIENTAL}

O termo comunicação gráfico-ambiental foi cunhado a partir da necessidade de diferenciar a comunicação visual tradicional, campo do design e das artes gráficas convencionais, da comunicação visual do tipo ambiental, resultado da combinação das novas tecnologias de produção de imagens, produtos e suportes, com o design gráfico e industrial, ao empregar recursos híbridos que misturam substratos e tecnologias digitais para a elaboração de peças normalmente acopladas a superfícies, reelaborando a ordem informacional que compõe o ambiente, em caráter permanente ou temporário. Também é conhecida como comunicação visual de grande formato ou, simplesmente, de sinalização; expressões rejeitadas por não atenderem a todos os aspectos formais ostentados atualmente pela CGA.
2. Id. Leituras sem palavras. São Paulo: Ática, 2004. p. 16.

3. FREIRE, Paulo. A importância do ato de ler. São Paulo: Cortez, 1992. p. 22.

4. FERRARA, Leituras sem palavras, op. cit., p. 16. 


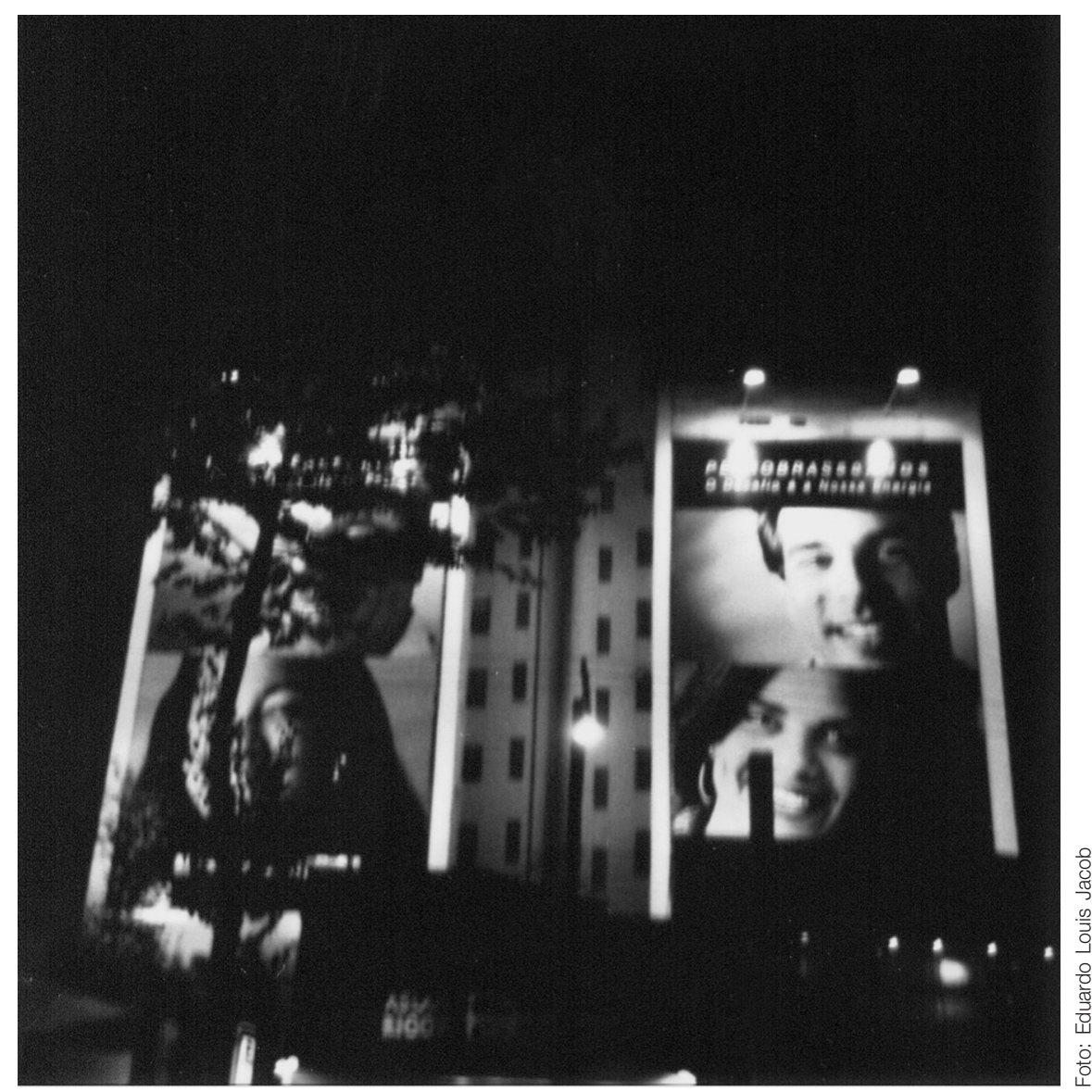

A comunicação gráfica ambiental: usando a cidade como suporte.

Sua irrefreável vocação proliferativa transforma em suporte o que se suporia não ser. A comunicação gráfico-ambiental instaura nos locais em que atua, com base em sua qualidade visível, a separação formal entre aparência e conteúdo estes preservados funcionalmente. Sua posição é entre meios; entre caminhos ou entre realidades, marcos referenciais que orientam e articulam conexões. Robert Venturi amarra essa discussão, recolocando-a no campo ambiental. Para ele, baseado em seus estudos sobre arquitetura, o inteiro é articulado pela inclusão de uma nova parte. Ele afirma que o contexto dá a um edifício sua expressão e, conseqüentemente, mudanças no contexto causam alterações na expressão. Se tomarmos a nova parte como sendo a CGA, dada sua inclusão em determinada cena, podemos imaginar uma mudança na expressão do ambiente. Com seu famoso diagrama do pato e o galpão decorado ${ }^{5}$, Venturi celebra o modelo de prédio que surgiu para caracterizar as manifestações de contradições: um espaço em branco a ser preenchido (espaço vazio ou intervalo)

5. VENTURI, Robert; SCOTT BROWN, Denise. Aprendendo com Las Vegas. Tradução Pedro Maia Soares. São Paulo: Cosac \& Naify, 2003. p. 119. em caixa de concreto, cujos significado, função e ornamento são derivados dos símbolos conectados a ele, tanto atarraxados no topo do prédio ou posicionados no estacionamento virado para a avenida. A planta do edifício não importa mais; esse galpão pode abrigar uma fábrica ou uma igreja - o que difere uma de outra é o painel na fachada que informa qual o uso social do prédio. Ele 
defende uma arquitetura como suporte de outras linguagens, ou, como ele mesmo clama, como abrigo com símbolos por cima. A arquitetura com frente retórica e fundos convencionais, voltados a uso e abrigo.

Há tempos a CGA se estabeleceu nas cidades. Apenas recentemente, no entanto, adquiriu importância e conquistou atenção, motivada pelo acelerado desenvolvimento tecnológico incorporado à prática nestes últimos anos. A produção artesanal das peças restringia sua aplicação e disseminação, tornando sua utilização acessível a poucos. Antigamente, a CGA de qualidade era muito mais resultado da perícia manual de alguns artesãos, aproximando-a, em sua prática e aparência, das artes plásticas e do artesanato. Esses artesãos desenvolveram especialidades, como a elaboração de placas, pôsteres, muros, instalações, diretórios, fachadas e cenografias, seja lapidando fisicamente, seja colorindo as mensagens a serem transmitidas. Assim, diante das dificuldades habituais de um trabalho artesanal, as peças eram onerosas e demoradas, tornando seu uso restrito. Sua principal característica, convém ressaltar, era de permanência por tempo indeterminado. Eram peças que ficavam décadas nos locais onde eram posicionadas e correspondiam aos preceitos arquiteturais dessas épocas, nas quais eram valorizadas características como durabilidade, solidez e perenidade. Ao se transformar da forma dimensional e estanque, densa e escultural para a presença plástica e efêmera, imagética e fugaz dos dias de hoje, a CGA multiplicou muito sua capacidade de interlocução. $\mathrm{O}$ início desse processo se deu nas cidades à medida que as multidões passaram a ser notadas como fenômeno moderno. A CGA cresceu e se alastrou no mesmo ritmo que as cidades, como um efeito colateral do processo de urbanização, fruto de uma sociedade urbana emergente.

Os gráficos ambientais são peças posicionadas no meio do nosso caminho. É impossível deambular pela cidade sem reparar nas peças de comunicação. Outdoors, placas, totens, luminosos, cartazes, faixas, banners, adesivos, veículos e muitos outros. A lista de aplicações é extensa. A CGA pode produzir, hoje em dia, peças com dimensões gigantescas, antes inimagináveis, com um ganho em escala de produção até então nunca adotado. Rápida, simultânea e globalmente, pode-se espalhar comunicação em cidades inteiras. É possível percebê-la em parques, eventos, shows, exposições e comícios, tanto em áreas externas quanto internas. Também é extensamente utilizada em shopping centers, aeroportos, avenidas, lojas, museus, enfim, todos os lugares onde há presença e fluxo de pessoas. No jargão publicitário, o termo mídia exterior indica a existência de placas, outdoors e luminosos, entre outros, que veiculam mensagens publicitárias. É evidente que o uso publicitário da CGA é amplamente reconhecido, porém convém sublinhar que não devemos entender que uma coisa equivale à outra. A CGA não serve só aos domínios publicistas. Existe, sem dúvida, uma climatização do ambiente urbano com aspectos relacionados ao consumo, mas cair no erro de entender essa perspectiva como sendo a única componente do universo comunicacional ambiental seria observar só uma das partes do fenômeno. 
comunicação \& educação • Ano XI • Número 3 • set/dez 2006

\section{ESTAÇÕES DE METRÔ: O NÃO-LUGAR CONECTADO}

O fluxo revela o movimento das coisas. Nas megacidades, a vida é agitada. O fluxo interage com os fixos continuamente. As vias são as conexões que ligam os diversos pontos das cidades. Os mega buildings e a compartimentalização da vida em microrregiões representam a possível nova organização das cidades. As vias expressas para os transportes individual e coletivo ultra-rápidos serão a solução para o deslocamento nessa nova estrutura. A relação que os indivíduos elaboram entre essas realidades é mediada pelos não-lugares; como definido por Marc Augé, são "espaços constituídos em relação a certos fins (transporte, trânsito, comércio, lazer) e a relação que os indivíduos mantêm com esses es-

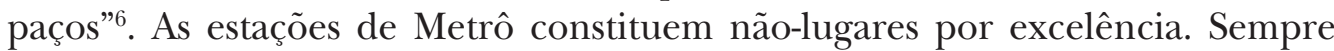
pontos de passagem, espaços não vivenciados.

Os não-lugares reais da supermodernidade são essas experiências de mediação de discursos dos indivíduos em pleno deslocamento, convertendo, pelo modo de usar, todo o sistema de objetos em comunicação. Para Augé, o "viajante fica de certo modo dispensado de parar e até mesmo de olhar" os pontos das cidades, bastando ler os comentários nas sinalizações.

\section{O METRÔ DE SÃO PAULO}

A Companhia do Metropolitano de São Paulo - Metrô foi constituída no dia 24 de abril de 1968 e as obras da Linha Norte-Sul, iniciadas oito meses depois. Em 1972, a primeira viagem de trem foi realizada entre as estações Jabaquara e Saúde. Em 1974, o trecho Jabaquara-Vila Mariana começou a operar comercialmente. Hoje, o Metrô de São Paulo é responsável pela operação e expansão do transporte metroviário, sistema de alta capacidade e articulador

6. AUGÉ, Marc. Não-lugares: introdução a uma antropologia da supermodernidade. Tradução Maria Lúcia Pereira. 4. ed. Campinas: Papirus, 2004. p. 87.

7. Ibid., p. 89.

8. O Metrô de São Paulo concluiu em 2006 a expansão de $3,5 \mathrm{~km}$ de extensão na Linha 2-Verde. Em 2007 está prevista a conclusão da Linha 4-Amarela, com etapa inicial de $12,8 \mathrm{~km}$ de vias entre o pátio de Vila Sônia e a Estação Luz, compreendendo cinco estações: Butantã, Pinheiros, Paulista, República e Luz. (N.E.)

9. Disponível em: <http:// www.metro.sp.gov.br> Acesso em: out. 2003. do transporte público na região metropolitana. Possui 57,6 km de extensão em quatro linhas e 52 estações. As linhas 1-Azul (Jabaquara-Tucuruvi), 2-Verde ${ }^{8}$ (Ana Rosa-Vila Madalena) e 3-Vermelha (Corinthians-Itaquera-Barra Funda) funcionam todos os dias, inclusive sábados, domingos e feriados, a partir das 4h40. Já a Linha 5-Lilás (Capão Redondo-Largo Treze) opera de segunda a sexta-feira, exceto feriados, das 5 às 22 horas. O sistema está integrado à CPTM nas estações Brás, Barra Funda, Tatuapé, Corinthians-Itaquera e Santo Amaro e aos outros modais de transporte na cidade de São Paulo. Diariamente, o Metrô transporta, em média, 1,7 milhão de passageiros ${ }^{9}$.

Esse transporte é apontado por especialistas como uns dos melhores do mundo. Sua operação é confiável, rápida e eficiente. Seus usuários demonstram satisfação em usar seus serviços e o fazem diariamente. Reconhecidamente é o meio que menos agride a cidade e seus cidadãos e sempre o apontam como solução aos problemas crônicos de transporte em massa de uma cidade como São Paulo. A opção que a cidade fez a favor dos veículos automotivos trouxe um ônus cujas mazelas atormentam a população todos os dias. A quantidade absurda e irracional de horas humanas desperdiçadas em congestionamentos monstruosos, o desgaste emocional, as toneladas de gases que se acumulam na 
atmosfera geram estresse e uma gravíssima incidência de doenças respiratórias na população, principalmente entre as crianças; a degradação arquitetônicourbanística de quilômetros de avenidas e arredores são resultado de uma ação fracassada de se privilegiar o transporte individual em carros e o coletivo em ônibus. O Metrô destoa nesse cenário como exemplo positivo de meio de transporte limpo, rápido e que preserva a paisagem urbana.

Entretanto, nem tudo no Metrô possui essa aura de sucesso. É meio de transporte coletivo restrito a um número limitado de usuários, devido, em grande parte, à lentidão de sua expansão. Como comparação, o Metrô da Cidade do México, inaugurado em data próxima ao de São Paulo, é hoje três vezes mais extenso.

\section{PERFIL DO USUÁRIO}

O Metrô é um meio de transporte utilizado por pessoas de todas as classes sociais, com predominância daquelas das camadas médias, com renda familiar de 10 salários mínimos e grau de instrução entre o ensino médio completo e superior incompleto. Existe um equilíbrio entre os usuários quanto ao sexo, com leve superioridade numérica dos homens (54\%), e igualdade quanto à faixa etária: $50 \%$ são jovens até 34 anos. A grande maioria dos seus usuários (84\%) recorre ao transporte com freqüência maior que três vezes por semana. De acordo com o próprio Metrô, existe a figura do usuário-padrão, embora as três linhas atendam a áreas diferentes entre si.

\section{PROGRAMAS DE CULTURA E ARTE NO METRÔ}

O Programa Ação Cultural se caracteriza por ações transitórias de cunho artísticocultural, cujo objetivo é agregar qualidade ao relacionamento do Metrô com a população. O programa consiste em atividades culturais que vão desde exposições de arte e temáticas até espetáculos musicais e de artes cênicas com periodicidade indeterminada, seguindo tendência mundial para desenvolver programação cultural no interior de suas dependências.

O Arte no Metrô é um projeto consistente e contínuo. A partir de 1978, esculturas, murais e painéis, assinados por artistas plásticos de renome, invadiram a praça e os espaços internos da Estação Sé, compondo um cenário inusitado para os olhos da maioria. A partir de 1988,

percebendo que as concepções construtivas das estações permitiam a utilização da arte, o Metrô iniciou um programa que objetivava contato mais íntimo com o usuário. Instituiu um processo experimental de aproximação entre o usuário e a obra de arte, com a colocação de obras em alguns espaços disponíveis e momentos especiais ${ }^{10}$.

O projeto consiste basicamente na instalação de obras de arte contemporânea brasileira nas estações. São esculturas, painéis, instalações e pinturas
10. COMPANHIA DO METROPOLITANO DE SÃO PAULO. Arte no Metrô. São Paulo: Alter Market, 1994. p. 10. 
produzidas por artistas plásticos. Essas peças integram-se à arquitetura dos ambientes, colorindo seu trajeto e convidando à contemplação.

A proposta do Metrô é que exista uma valorização da arquitetura com a integração das obras de arte, causando nos transeuntes novas percepções da arte. Pretende com isso, também, uma maneira de se comunicar com o usuário e, a partir desses elementos artísticos, transmitir mensagens educativas que o estimulem a apreciar obras de arte e a respeitar os espaços coletivos que utiliza em seu cotidiano.

\section{PROPOSTA DA INSTALAÇÃO DE POESIA NO METRÔ}

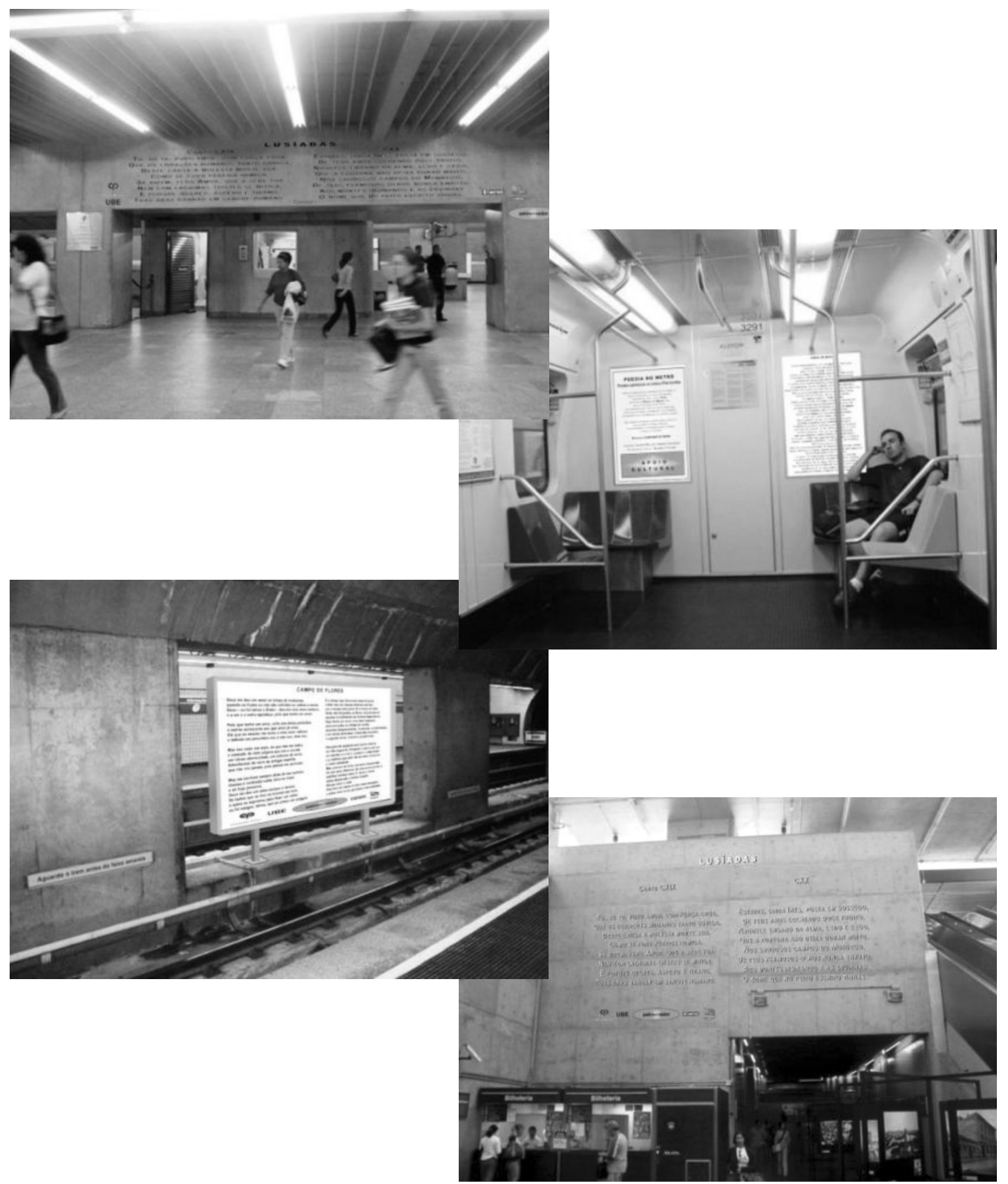

Fotos do projeto original de Antonio Peticov. 
O projeto Poesia no Metrô foi sugerido pela Companhia de Poesia, em parceria com a União Brasileira de Escritores - UBE, com supervisão do escritor e poeta Carlos Figueiredo e programação visual do artista plástico Antonio Peticov. Em sua concepção original, propunha "incrementar a exposição do texto poético à população brasileira"11, através da implantação de poemas em estações de Metrô com todos os suportes físicos que se apresentem convenientes para que os usuários possam contemplá-los.

Na fase 1 do projeto os poemas ficarão expostos nas oito estações da Linha 2-Verde (ramal da avenida Paulista) e nos vagões dos trens que circulam nessa linha. Quanto à sua forma, serão dispostos nos locais por onde os usuários transitam: paredes, colunas, corredores e vãos livres servirão de suporte para o posicionamento dos poemas. Essa fase tem duração inicial prevista de seis meses, em duas edições de três meses cada, com a troca dos poemas entre elas, garantindo o caráter de atração.

Pretende-se expor composições poéticas de Camões, Sá de Miranda, Castelo Branco, Gregório de Matos, Cláudio Manuel da Costa, Gonçalves Dias, Castro Alves, Cruz e Sousa, Alphonsus de Guimaraens, Cesário Verde, Augusto dos Anjos, Fernando Pessoa, Sá-Carneiro, Camilo Pessanha, Manuel Bandeira, Cecília Meireles, Oswald de Andrade, Mário de Andrade, Jorge de Lima, Carlos Drummond de Andrade e João Cabral de Melo Neto, entre outros.

Duas técnicas principais serão utilizadas para a aplicação dos textos, com os recursos da CGA. A primeira delas, para a instalação dos poemas nas paredes e nos vãos - suporte de lona vinílica - é a do recorte eletrônico de vinil adesivo. Pela visão de Antonio Peticov, é para dar a impressão de que as letras foram esculpidas em baixo-relevo. A segunda técnica é a da impressão digital tanto em papel como em vinil adesivo ou lona vinílica. Essas técnicas possibilitam que as peças sejam feitas uma a uma, de acordo com sua especificidade.

\section{O GESTOR E A POESIA NO METRÔ}

O gestor de processos comunicacionais é aquele profissional preocupado em exercer uma intermediação entre o indivíduo receptor e o local de origem da comunicação, através de uma mediação seja cultural, seja tecnológica, capaz de romper a barreira hegemônica dos meios de comunicação de massa, tornando o receptor crítico e não mais passivo, ao questionar a comunicação recebida no ato da recepção. De acordo com Barbero, perverter

[...] o projeto hegemônico que nos faz submergir numa crescente onda de fatalismo tecnológico, e frente ao qual resulta mais necessário do que nunca manter a estratégica tensão epistemológica e política entre as mediações históricas que dotam os meios de sentido e alcance social e o papel de mediadores que eles possam estar desempenhando hoje ${ }^{12}$.

O gestor precisa ser capaz de identificar os campos e locais para intervir e tornar o processo comunicacional equilibrado dentro da inter-relação emissão/recepção. Será, portanto, o mediador, assumindo um papel de elo e nexo
11. FIGUEIREDO, Carlos. Poesia no Metrô, extraído do texto original do projeto.

12. MARTÍN-BARBERO, Jesús. Dos meios às mediações. 2. ed. Rio de Janeiro: Editora UFRJ, 2001. p. 12. 
comunicação \& educação • Ano XI • Número 3 • set/dez 2006

entre as partes e entre os interesses diversos, assim como também entre as linguagens existentes no processo.

A comunicação se estabelece em uma via de duplo sentido, adquirindo caráter dialógico, no qual o receptor também é ativo e identificado como responsável pela atribuição de significados para a comunicação que lhe é dirigida. Por sua vez, ele mesmo se assume como gerador de nova comunicação e significados para o mundo em sua volta.

O presente trabalho visa dar roupagem de gestão de comunicação ao projeto Poesia no Metrô. Para que o trabalho tenha essa característica é necessário que o gestor se coloque como interlocutor entre os organizadores e os usuários do Metrô, no papel de receptores. É preciso saber as idéias que orientarão a intervenção e, além disso, conhecer o público que tomará contato com essas idéias; e, dessa forma, elaborar diálogos entre as partes. Um lado deve aceitar a existência do outro.

\section{O PROBLEMA DE PESQUISA}

Pretendeu-se descobrir se o projeto Poesia no Metrô é apropriado ao público ao qual se destina, quanto à sua temática e à sua aparência. $\mathrm{O}$ gestor procurou avaliar se o referencial do público é adequado para absorver o tema do projeto e como ele gostaria que o tema fosse exposto. O gestor quer saber se há imposição dos organizadores ou se foi pensado algum tipo de adequação do projeto para o repertório atual do público. Deseja aferir a intenção por parte dos organizadores de elaborar uma ação participativa do público ou se estes o impõem de maneira unidirecional. Quer também conhecer o público com o qual estará lidando e de quais maneiras os resultados da intervenção para os organizadores podem ser otimizados, possibilitando maior retorno às partes.

A realização da pesquisa espelha a mediação desejada pelo gestor: estabelecer o diálogo participativo entre os integrantes do processo e, a partir disso, avaliar, planejar e executar a proposta de intervenção que sirva a esse processo comunicativo.

A pesquisa procurou ouvir o público que seria atingido pela intervenção, no lugar onde esta se daria - nas estações de Metrô -, registrando-se as respostas em gravador portátil. A metodologia na pesquisa foi desenvolver e executar pesquisa empírica, com trabalho de campo e pesquisa bibliográfica. As técnicas de coleta de dados utilizadas foram: dados estatísticos sobre o perfil dos usuários do Metrô; uma abordagem de observação indireta associada à técnica de entrevistas qualitativas, do tipo perguntas abertas; e pesquisa bibliográfica. Foram usados dados primários.

As entrevistas aconteceram na saída da estação Vila Madalena, em dois dias e em horários semelhantes, à tarde, após o horário do almoço. Essa estação faz parte da lista das primeiras estações selecionadas a receberem os poemas, na fase 1 do projeto. As abordagens foram aleatórias, aceitando dar entrevistas quem se sentisse disposto a colaborar, e as conversas, todas gravadas. Seguiu-se um roteiro de perguntas para orientação única do pesquisador, do tipo abertas, 
estimulando, dentro do possível, os entrevistados para que suas respostas fossem expositivas. Para alguns o tema era muito distante da sua realidade, e muitos ficaram surpresos ao perceberem que falávamos de poesia.

\section{QUESTIONÁRIO APLICADO}

A. Perguntas para identificação pessoal do usuário:

1. Qual o seu nome?

2. Qual sua idade?

3. Qual o local de seu nascimento?

4. Pode me dizer seu grau de instrução?

5. Trabalha atualmente?

B. Perguntas para indicação do nível de utilização do Metrô:

1. Quantas vezes por semana você anda de Metrô?

2. Usa outro meio de transporte?

C. Perguntas para avaliação do referencial de poesia dos usuários do Metrô:

1. O que é poesia para você?

2. Você se lembra de algum poeta?

3. Você tem livros de poesia em casa?

D. Perguntas para avaliação da adequação do uso do local:

1. Qual sua opinião caso fossem colocadas poesias espalhadas nos locais por onde você passa no Metrô?

2. Você as leria?

3. Qual outro local indicaria para a colocação de poesias?

4. Como você gostaria que as poesias estivessem dispostas? Na forma escrita ou associadas a imagens?

5. Tem visto alguma atividade cultural no Metrô ultimamente?

6. Qual atividade cultural você gostaria que houvesse no Metrô?

\section{ANÁLISE DAS ENTREVISTAS}

Quanto ao referencial de poesia registrado nos entrevistados concluiu-se, com base nas respostas, que a poesia é sempre relacionada com algo positivo, cuja lembrança incita entusiasmo. Identificou-se o conceito original de poesia em alguns dos entrevistados. Para alguns, está relacionada com elevação do espírito, tanto que a confundem com religião, por arrebatar e sensibilizar como a poesia. Outra parte relacionou poesia com sentimentos. Reconheceram a poesia como envolta numa atmosfera lúdica, carregada de elementos oníricos, representante de um mundo sensível. A poesia expressa os sentimentos. Outros carregaram na visão tecnicista. Para estes a poesia é fruto de uma construção da linguagem e resultado de um tipo de discurso, o poético. Há o grupo que vincula a poesia à música e a outras artes, sem associá-la diretamente com o texto escrito.

Dentre aqueles que lembraram nomes de poetas, os mais citados foram Carlos Drummond de Andrade, Fernando Pessoa e Manuel Bandeira, disparado os três mais populares. Uma vez explicada a proposta, praticamente todos 
comunicação \& educação • Ano XI • Número 3 • set/dez 2006

responderam que gostariam de ver poesias no Metrô, e de forma muito semelhante, variando apenas o nível de entusiasmo apresentado.

Quanto à apresentação das poesias, a maioria preferiu que estivessem ligadas a alguma forma de imagem. Outros as condicionaram ao ato de ter sua atenção despertada.

\section{PROPOSTAS DO GESTOR}

Poesia no Metrô fornecerá o acesso a um vasto universo, no qual muitos ainda não tiveram a oportunidade de adentrar. Por tudo o que foi discutido, o projeto articula-se com vários conceitos, trabalha com os limites entre o público e o privado, a arte e o comercial, a imagem e o texto. Muito do projeto está resolvido desde a sua proposição original. No entanto, há algumas posições à espera de melhor solução. O papel do gestor é justamente identificar essas fissuras no corpo do projeto e revelá-las tanto para os organizadores como para os usuários. Uma vez identificados, esses detalhes - nem erros nem problemas - podem ser redimensionados e conduzidos à exatidão.

O projeto lida com um objeto que é sensivelmente percebido como muito positivo por todas as pessoas. Em entrevista, Carlos Figueiredo mencionou a sua preocupação de que muitas pessoas poderiam achar poesia algo chato: "O que acontece não é que as pessoas não gostam de poesia, e sim que as pessoas foram levadas a acreditar, apoiadas nesse peso antiintelectual, anticultural, machista ou autoritário brasileiro, que a poesia é uma coisa chata, coisa afeminada etc.”. No entanto, as pessoas gostam de poesia, mas a presença dela não está relacionada com o seu cotidiano. Poucos afirmaram ter livros de poesia em casa. A grande maioria não soube sequer citar um nome de poeta. $\mathrm{E}$ os que citaram ficaram limitados aos nomes dos mais conhecidos. Uma ou outra voz disse que, mesmo assim, lê, pouca, poesia. A sensação é de que as pessoas realmente não têm acesso a esse mundo, apesar de inclinadas a gostar. Há certo antagonismo nessa afirmação: se gostam, porque não trazê-la para o seu cotidiano?

O Poesia no Metrô está configurado como a instalação de poemas nas estações. O ato de desfrutar desses poemas fica a cargo dos usuários. No entanto, apesar de estes perceberem poesia como algo bom, a apreciação é ocasional. Essa é uma fratura do projeto: se mantida essa configuração, a apreciação da poesia vai continuar sendo ocasional, antes, durante e após a edição do evento. Isso porque o referencial das pessoas é de baixa densidade, e manter o estímulo torna-se complicado. A solução pode passar pelo acompanhamento de profissionais que monitorassem a apreciação, desempenhando um papel de educadores, e que também indicassem maneiras para que após as apreciações os usuários continuassem a desfrutar por si mesmos os poetas elencados na exposição.

O conjunto dos poemas poderia ser impresso em folhetos e distribuído ao público. Isso complementaria a ação. Pontos de distribuição posicionados estrategicamente nas estações, perto dos poemas, incentivariam as pessoas a retirarem seus catálogos, além de estabelecer um contato imediato com o público. A idéia é construir quiosques de pequeno formato, com monitores 
incentivando as pessoas a retirarem seu exemplar. Tal ação dependeria de um patrocínio que arcasse com os custos, já que há preocupação explícita do organizador em promover uma edição de lançamento simples, respeitando-se um limite racional de custos operacionais.

Os poemas devem ser mais variados quanto à sua origem (de onde), à sua temática (sobre o que trata) e sua forma (curto, longo, largo, alto). É necessário dar movimento e evitar a repetição, sendo fundamental acrescentar conteúdo imagético ao projeto. Embora as letras grandes, esculpidas nas paredes, abandonem sua origem textual e se transformem em imagens, a inclusão de outras figuras foi solicitada por quase todos os usuários entrevistados, acrescentando cor e movimento aos poemas. Muitos enfatizaram que leriam os poemas somente caso sua atenção fosse seqüestrada. Fazer isso, segundo eles, depende da adoção de imagens. Imagens estáticas e em movimento poderiam ser recursos considerados na intervenção.

O projeto Poesia no Metrô mostrou-se uma plataforma prolífera para a discussão de temas e conceitos adjacentes à implantação da exposição nas estações. Tantas são as derivações que se destacam do projeto, que sinalizam para uma evidente riqueza que emerge da leitura das outras tantas possibilidades que o projeto apresenta em seu núcleo epistemológico. Partindo do pressuposto de que o uso da comunicação gráfico-ambiental com cunho artístico, cultural e educacional vai muito além do seu propagado uso comercial e arquitetural, o gestor de comunicação escolheu a CGA como caminho para revelar outros sentidos a serem explorados pela área. A experiência de incentivar os usuários à leitura através de recursos de imagens técnicas potencializa a obtenção de resultados efetivos, permitindo a aplicação desses recursos em projetos semelhantes, com maior freqüência e alcance. Sabemos que somos atingidos por centenas de mensagens diariamente em nosso cotidiano. Mas vale se aproveitar daquelas que refletem o que temos de melhor como seres humanos.

Resumo: O projeto Poesia no Metrô pretende implantar poesia no interior das estações de Metrô. O processo é classificado e configurado como uma intervenção urbana e utilizará recursos técnicos da comunicação gráfico-ambiental. O presente artigo realiza uma análise dos seus elementos constitutivos e apresenta a figura do gestor de processos comunicacionais, cuja função é executar a mediação entre os autores do projeto e o público ao qual o empreendimento se destina, atribuindo um caráter de gestão da comunicação ao projeto.

Palavras-chave: comunicação gráfico-ambiental, cidades, paisagem urbana, poesia, arte, espaço público, Metrô.
Abstract: The project Subway Poetry intends to place poetry inside subway stations. The process is classified and structured as an urban intervention and it will utilize technical resources of visual environmental communication. This article analyses its main elements and presents the figure of the manager of the communication process, whose function is to mediate between the authors' project and the public to which the enterprise is destined, giving it the characteristic of communication gestion.

Keywords: visual environmental communication, cities, townscape, poetry, art, public space, subway. 